INTERVENTIONAL CARDIOLOGY AND SURGERY

\title{
Neuroprotection during cardiac surgery: a randomised trial of a platelet activating factor antagonist
}

\author{
D P Taggart, S M Browne, D T Wade, P W Halligan
}

Heart 2003;89:897-900

See end of article for authors' affiliations

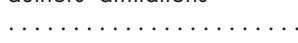

Correspondence to: Dr D P Taggart, John Radcliffe Hospital, Oxford OX39DU, UK;

david.taggart@

orh.anglox.nhs.uk

Accepted

21 February 2003

\begin{abstract}
Objective: To assess platelet activating factor (PAF) antagonists, potent neuroprotective agents in experimental cerebral dysfunction, in clinical practice.

Design: Double blind, minimised, placebo controlled trial of low and high dose PAF antagonist (lexipafant).

Setting: Cardiac surgery unit.

Patients: 150 patients undergoing coronary artery bypass graft (CABG) surgery using cardiopulmonary bypass.

Interventions: Randomisation to placebo, low dose $(10 \mathrm{mg})$ or high dose $(100 \mathrm{mg})$ lexipafant.

Main outcome measures: Incidence of impairment on four established cognitive tests, undertaken before, five days, and three months after CABG, examined by three methods for defining impairment. Results: The three groups were similar with respect to preoperative and intraoperative factors. Observed levels of cognitive impairment were less than had been predicted from previous studies. There was no difference in the groups in cognitive change scores at five days or three months. Group mean analysis showed significant time factors for all four tests but not for interactions or for the lexipafant group. A composite cognitive index, based on the aggregate of four normally distributed tests, showed a significant effect for timing of the test but not for the lexipafant group or interaction. Age, but not duration of bypass, was the most important determinant of postoperative cognitive impairment. Conclusions: The neuroprotective PAF antagonist lexipafant did not differentially reduce the level of cognitive impairment after $C A B G$ as determined by power estimates derived from published studies. The strongest predictors of cognitive impairment were age and timing of the test after operation.
\end{abstract}

C erebral dysfunction is a significant complication of coronary artery bypass graft (CABG) surgery using cardiopulmonary bypass (CPB). ${ }^{1}$ While overt neurological dysfunction occurs in 3\% of patients, cognitive dysfunction is detectable in most patients early after CABG and in up to half of patients at six months. ${ }^{1-4}$ Over the past decade several refinements to the conduct of $\mathrm{CPB}$ have reduced the incidence and severity of cognitive impairment but there have been few randomised trials of neuroprotective drugs. ${ }^{5}$

Platelet activating factor (PAF), an endogenous phospholipid intracellular signalling messenger, is also a potent inflammatory and neurotoxic agent. ${ }^{67}$ It produces cerebral damage by increasing intracellular calcium concentrations, disrupting the blood brain barrier, reducing cerebral blood flow, and stimulating leucocytes in damaged neuronal tissue. ${ }^{8-14}$ PAF antagonists limit the pathological, biochemical, and inflammatory consequences of experimental brain dysfunction with improvement in neurone survival and function. ${ }^{13-16}$

PAF and its metabolites are increased in patients with stroke ${ }^{17-20}$ and after CABG. ${ }^{21}{ }^{22}$ PAF antagonists reduce cerebral dysfunction in experimental cardiac surgery ${ }^{23}$ but have not been used after CABG. Lexipafant is an anti-inflammatory drug and a highly potent and specific antagonist of PAF. We evaluated the potential of lexipafant, in low and high doses, to reduce cognitive impairment in 150 patients undergoing CABG.

\section{METHODS}

The patients and methods have been described in detail elsewhere. ${ }^{23}$ Briefly, the Oxford research ethics committee approved the trial. Patients gave written consent to participation. Inclusion criteria were patients undergoing nonemergency first time CABG with no previous cerebrovascular accident and an ejection fraction $>30 \%$.
Lexipafant (British Biotech, Oxford, UK) is a highly potent and specific antagonist of PAF and in vitro binds to the PAF receptor with an affinity seven times that of PAF itself. It has an intravenous half life of about one hour and is well tolerated without serious adverse reactions.

Randomisation by minimisation was by a double blind process so that the treatment groups would be balanced with respect to age, sex, number of diseased vessels, previous percutaneous coronary intervention, surgeon, aspirin, and left ventricular function.

After loading doses of $0.4 \mathrm{mg}$ (low dose) or $4 \mathrm{mg}$ (high dose), lexipafant was infused at rates of $0.4 \mathrm{mg} /$ hour and $4 \mathrm{mg}$ /hour over 24 hours, achieving plasma concentrations of roughly $10 \mathrm{ng} / \mathrm{ml}$ and $100 \mathrm{ng} / \mathrm{ml}$, respectively.

Anaesthesia was standardised with morphine, scopolamine, fentanyl, pancuronium, etomidate, nitrous oxide, halothane, and propofol. Benzodiazepines were not used.

CABG was performed through a median sternotomy using non-pulsatile $\mathrm{CPB}$ and a temperature of $34^{\circ} \mathrm{C}$. Topical cooling, ventricular venting, and arterial filters were not used. A membrane oxygenator and alpha stat control of acid base management were used and the mean arterial pressure maintained at 50-60 mm Hg with pharmacological manipulation if necessary. Aortic clamping and induced fibrillation or cold crystalloid cardioplegia ( 15 patients) were used for distal anastomoses and a side biting clamp for proximal anastomoses.

Power calculations based on data from the mid-1980s suggested that three groups of 50 patients would be sufficient to

Abbreviations: $A M I B P$, adult memory and information processing battery; AVLT, auditory verbal learning test; $C A B G$, coronary artery bypass graft; $\mathrm{CPB}$, cardiopulmonary bypass; $\mathrm{PAF}$, platelet activating factor; TMTB, trail-making test B; VFT, verbal fluency test 
Table 1 Demographic data

\begin{tabular}{lllll}
\hline & Placebo & $10 \mathrm{mg}$ lexipafant & $100 \mathrm{mg}$ lexipafant & Total \\
\hline Number & 50 & 50 & 50 & 150 \\
Men & 42 & 46 & 43 & $131(87 \%)$ \\
Age (years) & $61.9(7.5)$ & $62.3(8.3)$ & $62.4(10.2)$ & $62.3(8.7)$ \\
Weight $(\mathrm{kg})$ & $81.5(12.7)$ & $85.1(13.1)$ & $82.6(19.5)$ & $83.3(15.3)$ \\
Height $(\mathrm{cm})$ & $173(9)$ & $174(10)$ & $172(10)$ & $173(9)$ \\
Body mass index $\left(\mathrm{kg} / \mathrm{m}^{2}\right)$ & $27.3(3.6)$ & $28.4(4.8)$ & $27.7(5.6)$ & $27.9(4.6)$ \\
Body surface area $\left(\mathrm{m}^{2}\right)$ & $1.97(0.18)$ & $2.01(0.19)$ & $1.98(0.26)$ & $2.0(0.21)$ \\
Elective/urgent surgery & $36 / 12$ & $38 / 10$ & $32 / 14$ & $106 / 36$ \\
Aspirin (yes/no) & $12 / 34$ & $12 / 35$ & $13 / 32$ & $37 / 101$ \\
Number of grafts & $2.8(0.6)$ & $2.8(0.6)$ & $2.7(0.6)$ & $2.8(0.6)$ \\
CPB time (min) & $64(17)$ & $65(15)$ & $67(23)$ & $65(18)$ \\
\hline Continuous variables are mean & $(\mathrm{SD}) . \mathrm{CPB}$, cardiopulmonary bypass. \\
\hline
\end{tabular}

obtain a $20 \%$ reduction in neuropsychological impairment with $80 \%$ power at the $1 \%$ level of significance at three months.

\section{Cognitive assessment}

Patients underwent a standard battery ${ }^{24}$ of 10 cognitive tests performed by one examiner (SMB) before surgery and at five days and three months after CABG. Only four tests (auditory verbal learning test (AVLT), adult memory and information processing battery (AMIBP), trail-making test B (TMTB), and verbal fluency test (VFT)) were normally distributed and these were used to calculate a composite cognitive index (see below).

In the absence of agreed consensus as to the optimal method for defining impairment ${ }^{12}$ three methods of analysis were used:

- Group mean: performance in each test was analysed with repeated measures analysis, using a within (time) and a between (lexipafant group) subject factor, with three levels.

- $20 \%$ definition: test deterioration was a $>20 \%$ fall in the preoperative score. The number of tests with $>20 \%$ deterioration was summed from zero to four.

- Composite cognitive index: the composite cognitive index was an estimate of overall performance, calculated from the mean of each patient's four test $\mathrm{z}$ scores (raw scores converted from mean $=0, S D=1$ ) at each time point.

\section{Statistical analysis}

S-PLUS2000 (MathSoft Inc, Seattle, Washington, USA) was used for statistical analysis. Differences between the groups were analysed using analysis of variance for continuous, Kruskal-Wallis for ordinal, and $\chi^{2}$ test for nominal data.
Within subject changes (from preoperation to discharge and to three month scores) were analysed using paired $t$ tests and between groups differences using Kruskal-Wallis. To account for multiple comparisons a significance was determined as $\mathrm{p}<0.005$ (that is, $0.05 / 8=0.006$, where 8 represents four tests at two time points).

To examine specifically the effects of drug dose, linear mixed effects models ${ }^{25}$ were fitted to each of the four psychometric tests using fixed covariates of lexipafant dose, test time, age, and duration of CPB. A quadratic effect was applied to test time to account for the early deterioration and subsequent improvement.

\section{RESULTS}

\section{Overall completeness of data}

The study was completed by 140 of the 150 patients enrolled. Of the 10 patients who did not complete the study, six died (three within one week of surgery and three during follow up) and the remaining four patients failed to attend at three months.

\section{Demographics}

Table 1 shows that the groups were similar regarding preoperative and intraoperative factors.

\section{Cognitive results}

Of the 150 trial patients 135 underwent all three assessments (although not necessarily completing the full battery). Reasons for patients not being assessed at both postoperative time points were death (six), stroke (two), refusal (four), medical instability (two), and irregular hospital discharge (one).

\begin{tabular}{|c|c|c|c|c|c|c|c|c|}
\hline \multirow[b]{2}{*}{ Test } & \multirow[b]{2}{*}{ Group } & \multicolumn{3}{|c|}{ Group mean (SD) } & \multirow[b]{2}{*}{ Number } & \multicolumn{3}{|c|}{ Significance of $F$} \\
\hline & & Preoperative & Discharge & Three months & & Drug & Time & Interaction \\
\hline \multirow[t]{3}{*}{ AVLT } & Placebo & $14.4(5.4)$ & $13.0(5.1)$ & $14.5(5.7)$ & 46 & 0.30 & 0.000 & 0.29 \\
\hline & 10 mg lexipafant & $14.4(5.4)$ & $11.8(5.9)$ & $13.6(6.1)$ & 45 & & & \\
\hline & $100 \mathrm{mg}$ lexipafant & $14.0(4.7)$ & $10.9(4.9)$ & $12.3(4.2)$ & 40 & & & \\
\hline \multirow[t]{3}{*}{ AMIPB } & Placebo & 61.3 (13.9) & $55.4(12.6)$ & $62.3(13.0)$ & 48 & 0.21 & 0.000 & 0.18 \\
\hline & 10 mg lexipafant & $57.4(14.7)$ & 49.9 (14.9) & $59.8(15.7)$ & 45 & & & \\
\hline & $100 \mathrm{mg}$ lexipafant & $57.0(10.3)$ & 49.5 (13.6) & 59.4 (1 1 1.8) & 41 & & & \\
\hline \multirow[t]{3}{*}{ TMTB (In) } & Placebo & $4.52(0.44)$ & $4.62(0.46)$ & $4.35(0.32)$ & 48 & 0.45 & 0.000 & 0.50 \\
\hline & $10 \mathrm{mg}$ lexipafant & $4.53(0.45)$ & $4.69(0.56)$ & $4.42(0.53)$ & 45 & & & \\
\hline & $100 \mathrm{mg}$ lexipafant & $4.58(0.41)$ & $4.80(0.63)$ & $4.45(0.45)$ & 42 & & & \\
\hline \multirow[t]{3}{*}{ VFT } & Placebo & 41.0 (13.5) & 40.2 (11.9) & 41.9 (13.5) & 47 & 0.05 & 0.001 & 0.50 \\
\hline & 10 mg lexipafant & $39.4(12.5)$ & 38.9 (12.2) & $42.7(12.1)$ & 43 & & & \\
\hline & $100 \mathrm{mg}$ lexipafant & $35.6(12.0)$ & 34.0 (11.6) & $36.3(10.9)$ & 39 & & & \\
\hline
\end{tabular}

AMIPB, test $A$ from the adult memory and information processing battery; AVLT, delayed recall on the auditory verbal learning test; TMTB, trail-making test $B$ ( following natural logarithmic conversion); VFT, verbal fluency test.

For AVLT, AMIPB, and VFT a higher score represents improved performance. TMTB is a timed test so that a higher score represents impaired performance. 
Table 3 Number of tests in which results of each patient declined by $20 \%$ at the two postoperative assessments

\begin{tabular}{lcc}
\hline $\begin{array}{l}\text { Number of tests that } \\
\text { declined by } 20 \%\end{array}$ & Predischarge & $\begin{array}{l}\text { Three } \\
\text { months }\end{array}$ \\
\hline 0 & 42 & 78 \\
1 & 42 & 48 \\
2 & 29 & 8 \\
3 & 9 & 1 \\
4 & 5 & 0 \\
Missing data & 8 & 0 \\
\hline
\end{tabular}

Table 4 Mean number of tests in which results of each patient declined by $20 \%$ in each group

\begin{tabular}{lccccc}
\hline & \multicolumn{2}{l}{ Predischarge } & \multicolumn{2}{l}{ Three months } \\
\cline { 2 - 3 } \cline { 5 - 5 } & Number & Mean (SD) & & Number & Mean (SD) \\
\hline Placebo & 46 & $0.87(0.93)$ & 48 & $0.48(0.62)$ \\
Low dose & 43 & $1.14(0.97)$ & & 45 & $0.49(0.66)$ \\
High dose & 38 & $1.52(1.29)$ & 42 & $0.52(0.67)$ \\
Total & 127 & & 135 & \\
\hline
\end{tabular}

\section{Group mean analysis}

All tests were impaired at discharge (table 2). By three months all had improved except for AVLT. The most important predictor of the change in scores was the time of testing.

\section{$20 \%$ definition}

The three treatment groups were marginally different at discharge (Kruskal-Wallis one way analysis of variance $\chi^{2}$ $6.20, \mathrm{p}=0.05)$, although not at the three month assessment (Kruskal-Wallis one way analysis of variance $\chi^{2} 0.11, p=0.9$ ) (tables 3 and 4).

\section{Cognitive composite index}

A repeated measures analysis with one within group factor (time of assessment) and one between group factor (lexipafant group), each with three levels, was used (table 5). The time factor again was significantly different $(F=69.8$, $\mathrm{p}=0.000)$. The lexipafant group factor was not significantly different $(F=1.45, \mathrm{p}=0.238)$. The interaction between the two factors was also insignificant $(F=1.12, \mathrm{p}=0.349)$. This indicates that the pattern of change for the three treatment groups was not significantly different.

\section{Predictors of changes in cognitive function}

There were no differences in baseline scores for any test between the three groups (table 6). The linear mixed effects model showed significant effects for timing of the test and age in predicting worse cognitive performance, but no significant effect of lexipafant or duration of CPB. Importantly, there was no detectable adverse reaction attributable to lexipafant.

\section{DISCUSSION}

Cognitive dysfunction after CABG is common and the rationale for the use of a PAF antagonist to reduce it is compelling. CABG using $\mathrm{CPB}$ induces high concentrations of $\mathrm{PAF}^{21}{ }^{22}$ which causes cerebral dysfunction in the clinical setting ${ }^{17-20}$ and which is ameliorated by PAF antagonists in experimental brain dysfunction. ${ }^{13-16}$

A major and unique strength of this trial was the use of three commonly used definitions of cognitive impairment. Our trial confirmed that age and timing of the test were the strongest predictors of cognitive impairment. ${ }^{1}$ The failure to identify duration of $\mathrm{CPB}$ as a predictor of decline is probably due to the relatively narrow spectrum of our CPB times.

It is unlikely that the dose of lexipafant was insufficient to achieve treatment effects. As a plasma concentration of lexipafant of $2 \mathrm{ng} / \mathrm{ml}$ blocks exogenous effects of PAF, a dose of $100 \mathrm{mg} / 24$ hour, providing plasma concentrations between 50 and $150 \mathrm{ng} / \mathrm{ml}$, should block exogenous PAF release in direct cell to cell interactions.

In retrospect, however, our trial may have been underpowered to detect a protective effect of lexipafant, as the incidence of cognitive impairment was less than had been expected. At three months only one test (delayed recall) had not returned to its baseline score. This is consistent with the findings of others ${ }^{5}$ and may also explain, in part, our failure to detect a difference in cognitive impairment in patients undergoing CABG with or without $\mathrm{CPB} .{ }^{2}$ If the overall improvement in surgical outcome is the result of ongoing refinements to the conduct of $\mathrm{CPB}$, then the negative findings of our study (which used studies from over a decade ago to calculate power) provide a valuable service to future studies. On the basis of the extent of cognitive impairment we detected postoperatively in this trial, 500 patients would have been needed to show efficacy of lexipafant.

Table 5 Change in composite cognitive index with time

\begin{tabular}{lllll}
\hline & & \multicolumn{2}{l}{ Composite cognitive index mean (SD) scores } \\
\cline { 3 - 5 } & Number & Preoperative & Predischarge & Three months \\
\hline Placebo & 46 & $+0.15(0.75)$ & $-0.08(0.74)$ & $+0.30(0.70)$ \\
Low dose & 43 & $+0.08(0.76)$ & $-0.24(0.80)$ & $+0.21(0.90)$ \\
High dose & 38 & $-0.01(0.60)$ & $-0.44(0.87)$ & $+0.03(0.57)$ \\
\hline
\end{tabular}

Table 6 Predictors of change in cognitive function

\begin{tabular}{lllllll}
\hline Test & Predischarge & $\begin{array}{l}\text { Three } \\
\text { months }\end{array}$ & Age & $\begin{array}{l}\text { CPB } \\
\text { time }\end{array}$ & $\begin{array}{l}10 \mathrm{mg} \\
\text { lexipafant }\end{array}$ & $\begin{array}{l}100 \mathrm{mg} \\
\text { lexipafant }\end{array}$ \\
\hline AVLTD & 0.08 & 0.05 & 0.000 & 0.6 & 0.7 & 0.1 \\
AMIPB & 0.000 & 0.000 & 0.000 & 0.9 & 0.2 & 0.1 \\
TMTB & 0.003 & 0.002 & 0.000 & 0.6 & 0.4 & 0.1 \\
VFT & 0.1 & 0.09 & 0.04 & 0.8 & 0.9 & 0.2 \\
\hline
\end{tabular}


While several drugs have been mooted as potential neuroprotective agents against cognitive dysfunction, there is only one other current large trial of a putative neuroprotective drug in CABG. ${ }^{5}$ In a randomised trial of 171 patients Arrowsmith and colleagues reported that remacemide, an $N$-methyl-D-aspartate receptor antagonist, did not significantly reduce cognitive dysfunction but did result in greater preservation of learning. ${ }^{5}$

Even accepting that the incidence of cognitive impairment is less than that observed a decade ago ${ }^{1}$ we do not advocate a complacent attitude. As cognitive dysfunction is an age related phenomenon it will remain an important consideration as a progressively elderly population with more comorbidity undergoes CABG. ${ }^{1}$ This is likely to be of even greater relevance in open operations where the risk of cerebral dysfunction is greater. ${ }^{26}$

\section{Conclusions}

Despite persuasive experimental evidence for the neuroprotective effects of PAF antagonists, we failed to detect such an effect in a large clinical trial. It is possible that our trial was, in retrospect, underpowered given the apparent reduction in overall cognitive impairment resulting from CABG that has occurred over the past decade. As older patients with greater comorbidity are referred for $\mathrm{CABG}$, however, the clinical need for innovative cerebral protective strategies remain compelling.

\section{ACKNOWLEDGEMENTS}

We thank British Biotech, and especially Dr Lloyd Curtis, for financial and organisational support for this trial, Miss Tessa Longney for administrative support, the anaesthetic and nursing staff for their assistance in ensuring appropriate drug administration, and Mr R Pillai for allowing his patients to be enrolled in the study. Support: British Biotech supported SMB.

\section{Authors' affiliations}

D P Taggart, S M Browne, Department of Cardiac Surgery, John Radcliffe Hospital, Oxford, UK

D T Wade, Rehabilitation Centre, Rivermead, Oxford, UK

P W Halligan, School of Psychology, Cardiff University, Cardiff, UK

\section{REFERENCES}

1 Taggart DP, Westaby S. Neurological and cognitive disorders after coronary artery bypass grafting. Curr Opin Cardiol 2001;16:271-6

2 Browne SM, Halligan PW, Wade DT, et al. Cognitive performance after cardiac operation: implications of regression towards the mean.J Thorac Cardiovasc Surg 1999;117:481-5.

3 Taggart DP, Browne SM, Halligan PW, et al. Is cardiopulmonary bypass still the cause of cognitive dysfunction after cardiac operations. J Thorac Cardiovasc Surg 1998;118:414-20.
4 van Dijk D, Keizer AM, Diephuis JC, et al. Neurocognitive dysfunction after coronary artery bypass surgery: a systematic review. J Thorac Cardiovasc Surg 2000;120:632-9.

5 Arrowsmith JE, Harrison M, Newman SP, et al. Neuroprotection of the brain during cardiopulmonary bypass. A randomized trial of remacemide during coronary artery bypass in 171 patients. Stroke 1998:27:2357-62

6 Bazan NG. A signal terminator. Nature 1995;374:501-2.

7 Imaizumi TA, Stafforini DM, Yamada Y, et al. Platelet-activating factor: a mediator for clinicians. J Intern Med 1995;238:5-20.

8 Lindsberg PJ, Yue T-L, Grericks KU, et al. Evidence for platelet-activating factor as a novel mediator in experimental stroke in rabbits. Stroke 1990:21:1452-7.

9 Kochanek PM, Nemoto EM, Melick JA, et al. Cerebro-vascular and cerebrometabolic effects of intracarotid infused platelet-activating factor in rats. J Cereb Blood Flow Metab 1988;8:546-51.

10 Sawyer DB, Anderson OS. Platelet-activating factor is a general membrane perturbant. Biochem Biophys Acta 1989;987:129-32.

11 Del Zoppo GJ. Microvascular responses to cerebral ischemia/ inflammation. Ann NY Acad Sci 1997:823:132-47.

12 Uhl E, Pickelmann S, Baethmann A, et al. Influence of platelet-activating factor on cerebral microcirculation in rats. Part 1. Systemic application. Stroke 1999;30:873-9.

13 Panetta T, Marcheselli VL, Braquet P, et al. Effects of a platelet activating factor antagonist (BN 52021) on free fatty acids, diacylglycerols, polyphosphoinositides and blood flow in the gerbil brain: inhibition of ischaemia-reperfusion induced cerebral dysfunction. Biochem Biophys ischaemia-reperfusion induced cereh
Res Commun 1987; 149:580-7

14 Prehn JH, Krieglstein J. Platelet-activating factor antagonists reduce excitotoxic damage in cultured neurons from embryonic chick telencephalon and protect the rat hippocampus and neocortex from ischemic dysfunction in vivo. J Neurosci Res 1993:34:179-88.

15 Oberpichler H, Sauer D, Rossberg C, et al. PAF antagonist ginkgolide B reduces postischemic neuronal damage in rat brain hippocampus. J Cereb Blood Flow Metab 1990;10:133-5

16 Faden AI, Tzendzalian PA. Platelet-activating factor antagonists limit glycine changes and behavioral deficits after brain trauma. Am J Physiol 1992:263:R909-14.

17 Frerichs KU, Fevestein GZ. Platelet-activating factor: key mediator in neurodysfunction? Cerebrovasc Brain Metab Rev 1990;2:148-60.

18 Lindsberg PJ, Hallenbeck JM, Feverstein G. Platelet-activating factor in stroke and brain dysfunction. Ann Neurol 1991;30:117-29.

19 Satoh K, Yoshida H, Imaizumi T, et al. Platelet-activating factor acetylhydrolase in plasma lipoproteins from patients with ischemic stroke. Stroke 1992:23:1090-2.

20 Satoh K, Imaizumi T, Yoshida H, et al. Increased levels of blood platelet-activating factor (PAF) and PAF-like lipids in patients with ischemic stroke. Acta Neurol Scand 1992;85:122-7

21 Hoshikawa-Fujimura AY, Auler Junior JO, Da Rocha TR, et al. PAF-acether, superoxide anion and beta-glucuronidase as parameters of polymorphonuclear cell activation associated with cardiac surgery and polymorphonuclear cell activation associated with cardiac surgery and
cardiopulmonary bypass. Braz J Med Biol Res 1989;22:1077-82.

22 Schlame M, Schmid AB, Haupt R, et al. Study of platelet-activating factor acetylhydrolase in the perioperative period of patients undergoing cardiac surgery. Shock 1998;9:313-9.

23 Langley SM, Chai PJ, Jaggers JJ, et al. Platelet-activating factor receptor antagonism improves cerebral recovery after circulatory arrest. Ann Thorac Surg 1999;68:1578-85.

24 Murkin JM, Newman SP, Stump DA, et al. Statement of consensus on assessment of neurobehavioural outcomes after cardiac surgery. Ann Thorac Surg 1995:59:289-95.

25 Vonesh EF, Chinchilli VM. Linear and nonlinear models for the analysis of repeated measurements. New York: Marcel Dekker, 1997.

26 Wolman RL, Nussmeier NA, Aggarwal A, et al. Cerebral dysfunction after cardiac surgery. Identification of a group at extraordinary risk. Stroke 1999;30:514-22. 